\title{
PERBEDAAN KADAR KOLESTEROL TOTAL SEBELUM DAN SESUDAH PEMBERIAN JUS KACANG HIJAU (Phaseolus radiatus Linn) PADA PRIA HIPERKOLESTEROLEMIA
}

\author{
R. Farah Amalia, Ahmad Syauqy ${ }^{*}$
}

Program Studi Ilmu Gizi Fakultas Kedokteran Universitas Diponegoro

Jl.Dr.Sutomo No.18, Semarang, Telp (024) 8453708, Email : gizifk@ undip.ac.id

\begin{abstract}
Background: High total cholesterol level is one of the risk factor for developing cardiovascular disease events. Mung bean contains of isoflavone, soluble fiber, and protein which can decrease total cholesterol level.

Objective: To determine the difference of serum total cholesterol level before and after consumption of mung bean juice in men with hypercholesterolemia.

Methods: This was pre-test and post-test with control group design. Subject were 28 men aged 40-58 years with serum total cholesterol level 200-250 mg/dl, classified into two groups, treatment group was consumed $400 \mathrm{ml}$ mung bean juice and control group was consumed packaged mineral water for 21 days. All subjects were given nutrition counseling before intervention. Nutritional intake were gathered using food recall method and processed with nutrisurvey. Data was analyzed by using Paired t-test, independent samples t-test, and Mann-Whitney.

Results: Mean of total cholesterol level before and after intervention in treatment group is 229,57 mg/dl and 218,50 $\mathrm{mg} / \mathrm{dl}$. There were differences in total cholesterol level before and after intervention in treatment group $(p=0,034)$. Mean of total cholesterol level before and after intervention in control group is 226,36 mg/dl and 240,29 mg/dl. There were differences in total cholesterol level before and after intervention in control groups $(p=0,004)$. There were differences on the changes in total cholesterol level between the two groups $(p=0,000)$.

Conclusion: Consumption of $400 \mathrm{ml}$ mung bean juice for 21 days was significantly decrease total cholesterol level in men with hypercholesterolemia.

Keywords: Mung bean juice; total cholesterol level; men; hypercholesterolemia
\end{abstract}

\section{ABSTRAK}

Latar belakang: Kadar kolesterol total darah yang tinggi merupakan salah satu faktor risiko kejadian penyakit kardiovaskuler. Kacang hijau mengandung isoflavon, serat larut dan protein yang dapat menurunkan kadar kolesterol total.

Tujuan: Mengetahui perbedaan kadar kolesterol total sebelum dan sesudah pemberian jus kacang hijau pada pria hiperkolesterolemia.

Metode: Penelitian ini merupakan rancangan control group pre test - post test. Subjek penelitian adalah 28 orang pria usia 40-58 tahun dengan kadar kolesterol total 200-250 mg/dl, dibagi menjadi dua kelompok yaitu kelompok perlakuan memperoleh jus kacang hijau $400 \mathrm{ml}$ dan kelompok kontrol memperoleh air kemasan selama 21 hari. Seluruh subjek diberikan konseling sebelum intervensi. Asupan makanan diukur menggunakan metode recall 24 jam selama intervensi dan dianalisis menggunakan program nutrisurvey. Data dianalisis menggunakan Paired t-test, independent samples t-test, dan Mann-Whitney.

Hasil: Rerata kadar kolesterol total sebelum dan sesudah intervensi pada kelompok perlakuan berturut-turut 229,57 $\mathrm{mg} / \mathrm{dl}$ dan 218,50 mg/dl. Terdapat perbedaan kadar kolesterol total sebelum dan sesudah intervensi pada kelompok perlakuan ( $p=0,034)$. Rerata kadar kolesterol total sebelum dan sesudah intervensi pada kelompok kontrol berturutturut 226,36 mg/dl dan 240,29 mg/dl. Terdapat perbedaan kadar kolesterol total sebelum dan sesudah intervensi pada kelompok kontrol $(p=0,004)$. Terdapat perbedaan perubahan kadar kolesterol total antara kedua kelompok $(p=0,000)$.

Simpulan: Pemberian jus kacang hijau dengan dosis $400 \mathrm{ml} / \mathrm{hari}$ selama 21 hari terbukti menurunkan kadar kolesterol total pria hiperkolesterolemia secara signifikan.

Kata kunci : Kacang hijau; kolesterol total; pria; hiperkolesterolemia.

\section{PENDAHULUAN}

Penyakit kardiovaskuler merupakan penyebab kematian utama di berbagai negara maju dan menunjukkan kecenderungan meningkat sebagai penyebab kematian di berbagai negara berkembang. ${ }^{1}$ Laporan World Health Organization (WHO) tahun 2008 menunjukkan 17,3 juta orang meninggal dunia per tahun akibat penyakit kardiovaskuler. $^{2}$ Menurut Direktorat Jenderal Pengendalian Penyakit dan Penyehatan Lingkungan (P2PL) dari tahun 2009-2010 penyakit jantung merupakan kasus terbesar Penyakit Tidak Menular (PTM) yaitu 3,65\% dan 3,20\% serta menjadi penyebab kematian utama sebesar $9,49 \%$ di Indonesia. ${ }^{1}$

\footnotetext{
${ }^{*}$ Penulis Penanggungjawab
} 
Kadar kolesterol total darah yang tinggi (hiperkolesterolemia) merupakan faktor risiko utama penyakit kardiovaskuler. ${ }^{3,4,5}$ Hiperkolesterolemia menempati posisi yang sangat penting karena merupakan faktor risiko independen yang dapat menyebabkan penyempitan pembuluh darah atau aterosklerosis. ${ }^{6,7}$ Risiko hiperkolesterolemia meningkat seiring dengan bertambahnya usia. Pria usia 40 tahun ke atas diketahui berisiko mengalami hiperkolesterolemia. Penelitian di Taiwan melaporkan bahwa pria usia 40-59 tahun berisiko 3,26 kali mengalami hiperkolesterolemia dibandingkan pria usia $<40$ tahun. ${ }^{4}$ Peningkatan kolesterol total $10 \mathrm{mg} / \mathrm{dl}$ berhubungan dengan 1,12 kali peningkatan penyakit kardiovaskuler pada pria dan wanita. ${ }^{6}$

Penurunan kadar kolesterol total merupakan target terapi primer dalam pencegahan penyakit kardiovaskuler. ${ }^{6,8}$ Berdasarkan National Center Heart Statistic (NCHS) pada tahun 20052006, pria usia 40-59 tahun memiliki rata-rata kolesterol total serum $205 \mathrm{mg} / \mathrm{dl}$ sedangkan wanita $189 \mathrm{mg} / \mathrm{dl}$ pada usia yang sama. ${ }^{9}$ Penelitian di Thailand tahun 2006 sebanyak $66,8 \%$ pria hiperkolesterolemia diderita pada kelompok usia 40-49 tahun. ${ }^{4}$ Data Riskesdas 2013 melaporkan penduduk Indonesia usia $\geq 15$ tahun sebanyak $35,9 \%$ memiliki kadar kolesterol total $\geq 200 \mathrm{mg} / \mathrm{dl}^{10}$

Asupan makanan erat kaitannya dengan hiperkolesterolemia. Konsumsi lemak berlebihan berhubungan dengan kadar kolesterol total darah yang tinggi. ${ }^{11}$ Studi metaanalisis melaporkan bahwa setiap penurunan $1 \%$ kalori dari asam lemak jenuh akan menurunkan serum kolesterol sebesar $2 \%$. Rata-rata peningkatan asupan kolesterol 100 $\mathrm{mg}$ /hari dapat meningkatkan serum kolesterol 2-3 $\mathrm{mg} / \mathrm{dl}^{6}{ }^{6}$ Selain itu peningkatan konsumsi karbohidrat akan meningkatkan konsentrasi insulin, sehingga diduga meningkatkan sintesis kolesterol total. ${ }^{12}$

Kacang hijau segar mengandung isoflavon tinggi yaitu $70,74 \mathrm{mg}$ per $100 \mathrm{~g}$ bahan terdiri dari daidzein, genistein, dan glisitein. ${ }^{13}$ Isoflavon ini merupakan fitoestrogen yang diketahui memiliki efek hipokolesterolemia yang dapat mencegah penyakit kardiovaskuler. ${ }^{14,15,16}$ Isoflavon dapat mengaktifkan enzim sitokrom P-450 dimana enzim ini mampu mengikat kolesterol menuju asam empedu, sehingga dapat meningkatkan ekskresi asam empedu dan menurunkan kadar kolesterol darah. ${ }^{17}$

Beberapa penelitian mengenai pemberian kacang hijau pada hewan coba terbukti menurunkan kolesterol total secara signifikan. Penelitian mengenai konsumsi jus kacang hijau 300 ml/hari selama 14 hari telah terbukti dapat menurunkan kolesterol total wanita hiperkolesterolemia. ${ }^{18}$

Berdasarkan uraian diatas, kacang hijau memiliki potensi untuk menurunkan kadar kolesterol total dalam darah. Jus kacang hijau merupakan salah satu jenis olahan kacang hijau dengan cara pengolahan yang sederhana dan mudah dikonsumsi. ${ }^{18}$ Studi yang dilakukan oleh American Association for Cancer Institute melaporkan bahwa olahan jus menghasilkan ukuran partikel yang lebih kecil sehingga dapat diserap tubuh lebih mudah daripada bentuk padat. ${ }^{19}$

Dosis kacang hijau yang diberikan adalah 85 gr/hari selama 21 hari. Penentuan dosis ini berdasarkan penelitian yang menyebutkan bahwa asupan isoflavon $40 \mathrm{mg} / \mathrm{hari}$ dapat menurunkan kadar kolesterol total. ${ }^{20,21}$ Pemberian isoflavon selama 21 hari telah menunjukkan efek positif dalam menurunkan kadar kolesterol. ${ }^{20}$

Penelitian ini bertujuan untuk mengetahui perbedaan kadar kolesterol total sebelum dan sesudah pemberian jus kacang hijau pada pria hiperkolesterolemia.

\section{METODE PENELITIAN}

Penelitian ini merupakan penelitian true experimental dengan rancangan control group pre test - post test. Variabel bebas dalam penelitian adalah pemberian jus kacang hijau, sedangkan variabel terikat adalah kadar kolesterol total.

Peneliti telah mendapatkan Ethical Clearance dari Komite Etik Fakultas Kedokteran Universitas Diponegoro. Pengambilan data sampel termasuk pemeriksaan darah dilakukan setelah mendapat persetujuan dari subjek dengan mengisi informed consent. Keterangan mengenai untung dan rugi mengikuti penelitian, serta efek samping dari intervensi dijelaskan kepada subjek oleh peneliti. Seluruh data subjek bersifat pribadi dan hanya digunakan untuk kepentingan penelitian.

Subjek penelitian adalah pria usia 40-58 tahun di kantor Sekretaris Daerah Provinsi Jawa Tengah, Badan Kepegawaian Daerah Kota Semarang, dan Dinas Sosial, Pemuda dan Olahraga. Kriteria inklusi penelitian diantaranya memiliki kadar kolesterol total $200-250 \mathrm{mg} / \mathrm{dl}$, memiliki indeks massa tubuh (IMT) $\geq 23-30 \mathrm{~kg} / \mathrm{m}^{2}$, tidak dalam kondisi sakit atau dalam perawatan dokter berkaitan dengan penyakit DM, PJK, dan penyakit kronis lainnya, tidak sedang mengkonsumsi obatobatan yang mengendalikan kadar kolesterol darah selama penelitian, merokok tidak lebih dari 10 batang/hari, tidak konsumsi alkohol, serta bersedia menjadi sampel penelitian dengan mengisi informed consent. 
Perhitungan jumlah subjek penelitian menggunakan rumus uji hipotesis terhadap rerata dua sampel independen dan dibutuhkan sebanyak 28 subjek. Penentuan subjek penelitian menggunakan metode consecutive sampling. Pada tahap awal dilakukan skrining menurut kriteria inklusi, meliputi wawancara data umum subjek, pengukuran berat badan dan tinggi badan, serta pemeriksaan kadar kolesterol total.

Subjek dibagi menjadi 2 kelompok menggunakan metode simple randomization, yang terdiri atas kelompok perlakuan dan kelompok kontrol, masing-masing kelompok terdiri dari 14 subjek. Kelompok perlakuan mendapatkan jus kacang hijau sebanyak $400 \mathrm{ml} / \mathrm{hari}$, sedangkan kelompok kontrol mendapatkan air minum kemasan. Pemberian jus kacang hijau dan air minum dilakukan selama 21 hari. Sebelum intervensi dilaksanakan, setiap subjek diberikan konseling menggunakan media leaflet mengenai diet yang dianjurkan bagi penderita hiperkolesterolemia. Cara pembuatan jus kacang hijau yaitu kacang hijau 85 gram direndam selama 8 jam, kemudian direbus selama 20 menit. Kacang hijau yang telah direbus didiamkan pada suhu ruangan kemudian diblender dan ditakar sebanyak $400 \mathrm{ml}$ dan ditambah pemanis buatan (gula jagung).

Asupan makan sehari-hari kelompok perlakuan dan kontrol diukur menggunakan metode recall 24 jam selama intervensi, kemudian dianalisis menggunakan program nutrisurvey.
Kepatuhan subjek mengkonsumsi jus kacang hijau dicatat menggunakan formulir kepatuhan. Kadar kolesterol total diperiksa dua kali, yaitu satu hari sebelum intervensi dan satu hari setelah intervensi (pada hari ke-22). Kadar kolesterol total dianalisis dengan pemeriksaan laboratorium menggunakan metode Cholesterol Oxidase Para Aminophenazone (CHOD-PAP). Sampel darah diambil oleh petugas laboratorium setelah subjek berpuasa 10-12 jam.

Untuk menguji kenormalan data menggunakan uji Saphiro-Wilk. Perbedaan kadar kolesterol total sebelum dan sesudah intervensi diuji menggunakan Paired t-test. Perbedaan kadar kolesterol total antara kedua kelompok dianalisis menggunakan independent samples t-test karena data berdistribusi normal, sedangkan untuk data berdistribusi tidak normal menggunakan uji MannWhitney.

\section{HASIL PENELITIAN \\ Karakteristik Subjek}

Pada skrining awal sebanyak 68 orang bersedia diambil darahnya dan diperoleh 28 orang yang memenuhi kriteria inklusi dan bersedia menjadi subjek penelitian. Semua subjek penelitian dapat menyelesaikan penelitian. Seluruh subjek berada pada rentang umur 40-58 tahun. Karakteristik subjek yang terdiri dari umur, indeks massa tubuh (IMT), dan kadar kolesterol total sebelum intervensi disajikan dalam tabel 1.

Tabel 1. Karakteristik subjek penelitian

\begin{tabular}{lccc}
\hline \multicolumn{1}{c}{ Variabel } & $\begin{array}{c}\text { Perlakuan } \\
(\mathbf{n = 1 4})\end{array}$ & $\begin{array}{c}\text { Kontrol } \\
(\mathbf{n = 1 4})\end{array}$ & \multirow{2}{*}{$\mathbf{p}$} \\
\cline { 2 - 3 } & Mean \pm SD & Mean \pm SD & \\
\hline Umur & $49,29 \pm 5,41$ & $48,64 \pm 4,55$ & $0,736^{\mathrm{a}}$ \\
Indeks Massa Tubuh & $25,8 \pm 2,22$ & $26,8 \pm 2,21$ & $0,260^{\mathrm{a}}$ \\
$23-24,9 \mathrm{~kg} / \mathrm{m}^{2}(n, \%)$ & $4(28,6)$ & $3(21,4)$ & \\
$25-30 \mathrm{~kg} / \mathrm{m}^{2}(n, \%)$ & $10(71,4)$ & $11(78,6)$ & \\
Kolesterol total sebelum intervensi & $229,57 \pm 16,51$ & $226,36 \pm 16,92$ & $0,615^{\mathrm{a}}$ \\
\hline
\end{tabular}

a independent samples $t$-test

Tabel 1 menunjukkan tidak terdapat perbedaan karakteristik subjek (umur, IMT, dan kadar kolesterol total sebelum intervensi) antara kelompok perlakuan dan kelompok kontrol $(\mathrm{p}>0,05)$.
Asupan energi, protein, lemak, karbohidrat, serat, dan kolesterol kelompok perlakuan dan kontrol

Tabel 2. Asupan energi, protein, lemak, karbohidrat, serat, dan kolesterol kelompok perlakuan dan kontrol

\begin{tabular}{lccc}
\hline \multicolumn{1}{c}{ Asupan makanan } & $\begin{array}{c}\text { Perlakuan } \\
(\mathbf{n = 1 4 )}\end{array}$ & $\begin{array}{c}\text { Kontrol } \\
(\mathbf{n = 1 4 )}\end{array}$ & $\mathbf{p}$ \\
\cline { 2 - 3 } & Mean \pm SD & Mean \pm SD & \\
\hline Energi & $1416 \pm 486,67$ & $1334 \pm 338,40$ & $0,612^{\mathrm{a}}$ \\
Protein & $46,12 \pm 16,97$ & $43,14 \pm 13,32$ & $0,358^{\mathrm{b}}$ \\
Lemak & $45,99 \pm 18,15$ & $38,15 \pm 13,82$ & $0,210^{\mathrm{a}}$
\end{tabular}




\begin{tabular}{lccc} 
Karbohidrat & $206,34 \pm 79,06$ & $207,37 \pm 48,60$ & $0,854^{\mathrm{b}}$ \\
Serat & $7,52 \pm 4,40$ & $6,96 \pm 2,0$ & $0,669^{\mathrm{a}}$ \\
Kolesterol & $184,25 \pm 100,13$ & $133,08 \pm 38,62$ & $0,092^{\mathrm{a}}$ \\
\hline${ }^{\mathrm{a}}$ independent samples $t$-test & \multicolumn{3}{c}{}
\end{tabular}

Tabel 2 menunjukkan tidak terdapat perbedaan asupan energi, protein, lemak, karbohidrat, serat dan kolesterol antara kelompok perlakuan dan kelompok kontrol ( $p>0,05)$.

\section{Kepatuhan konsumsi jus kacang hijau}

Selama penelitian kelompok perlakuan mendapat intervensi berupa jus kacang hijau sebanyak $400 \mathrm{ml}$. Terdapat 2 orang subjek menyisakan jus kacang hijau sebanyak 25\% selama 2 hari, hal ini disebabkan subjek telah merasa kenyang.

Perbedaan kadar kolesterol total sebelum dan sesudah intervensi pada kelompok perlakuan dan kontrol

Tabel 3. Perbedaan kadar kolesterol total sebelum dan sesudah intervensi pada kelompok perlakuan dan

\begin{tabular}{|c|c|c|c|}
\hline \multicolumn{4}{|c|}{ kontrol } \\
\hline \multirow[t]{2}{*}{ Variabel } & $\begin{array}{c}\text { Perlakuan } \\
(n=14)\end{array}$ & $\begin{array}{c}\text { Kontrol } \\
(n=14)\end{array}$ & \multirow[t]{2}{*}{$\mathbf{p}$} \\
\hline & Mean \pm SD & Mean \pm SD & \\
\hline \multicolumn{4}{|c|}{ Kolesterol total (mg/dl) } \\
\hline Sebelum intervensi & $229,57 \pm 16,51$ & $226,36 \pm 16,92$ & \\
\hline Sesudah intervensi & $218,50 \pm 21,53$ & $240,29 \pm 24,83$ & \\
\hline$\Delta$ & $-11,07 \pm 17,43$ & $13,93 \pm 14,85$ & $0,000^{\mathrm{b}}$ \\
\hline $\mathbf{p}$ & $0,034^{\mathrm{a}}$ & $0,004^{\mathrm{a}}$ & \\
\hline
\end{tabular}

Tabel 3 menunjukkan terdapat perbedaan kadar kolesterol total antara sebelum dan sesudah intervensi baik pada kelompok perlakuan maupun kelompok kontrol $(\mathrm{p}<0,05)$. Terdapat perbedaan perubahan kadar kolesterol total antara kelompok perlakuan dan kelompok kontrol $(\mathrm{p}<0,05)$.

\section{PEMBAHASAN}

Pada penelitian ini tidak terdapat perbedaan signifikan umur, IMT, dan kadar kolesterol total sebelum intervensi antara kelompok perlakuan dan kelompok kontrol, sehingga karakteristik subjek pada awal penelitian tergolong homogen.

Subjek dalam penelitian ini yaitu pria berusia 40-58 tahun yang mengalami hiperkolesterolemia. Pria usia 40 tahun keatas diketahui berisiko mengalami hiperkolesterolemia. ${ }^{4,11}$ Hal ini disebabkan adanya penurunan hormon testosteron yang dapat meningkatkan risiko hiperkolesterolemia. ${ }^{22}$ Hormon testosteron yang rendah juga berkaitan dengan risiko terjadinya aterosklerosis pada pria. ${ }^{23}$

Pada penelitian ini, pemberian jus kacang hijau sebanyak $400 \mathrm{ml} / \mathrm{hari}$ selama 21 hari berpengaruh terhadap kadar kolesterol total, ditunjukkan dengan hasil uji statistik terdapat perbedaan kadar kolesterol total antara sebelum dan sesudah intervensi $(\mathrm{p}<0,05)$. Hasil uji statistik juga menunjukkan bahwa terdapat perbedaan perubahan kadar kolesterol total antara kedua kelompok $(p<0,05)$. Hal ini sesuai dengan penelitian sebelumnya yang menunjukkan bahwa pemberian jus kacang hijau $300 \mathrm{ml} /$ hari selama 14 hari dapat menurunkan kadar kolesterol total wanita hiperkolesterolemia. ${ }^{18}$ Pada kelompok perlakuan yang diberikan jus kacang hijau terjadi penurunan rata-rata kadar kolesterol total sebesar 11,07 mg/dl. Konsumsi jus kacang hijau dapat memperbaiki kadar kolesterol total meskipun belum mencapai kadar normal. Namun demikian terdapat 4 orang kadar kolesterol total setelah penelitian mencapai nilai normal ( $<200 \mathrm{mg} / \mathrm{dl})$. Pada kelompok kontrol yang tidak diberikan jus kacang hijau dan hanya diberikan konseling terjadi peningkatan rata-rata kadar kolesterol total sebesar 13,93 mg/dl.

Kacang hijau diberikan pada kelompok perlakuan sebanyak 85 gram yang mengandung isoflavon sebesar $41,3 \mathrm{mg}$. Asupan isoflavon 40 $\mathrm{mg} /$ hari dapat menurunkan kadar kolesterol total melalui mekanisme pengaktifan enzim sitokrom P450 dimana enzim ini mampu mengikat kolesterol menuju asam empedu, sehingga dapat meningkatkan ekskresi asam empedu dan menurunkan kadar kolesterol darah. ${ }^{17}$ Isoflavon dalam kacang hijau terdiri dari daidzein, genistein, dan glisitein yang disebut fitoestrogen atau estrogen nabati yang berperan sebagai antioksidan. Genistein memiliki efek langsung dalam menghambat kerusakan oksidatif dari membran lipid dan lipoprotein serta kerusakan oksidatif DNA. ${ }^{14}$

Penurunan kadar kolesterol total juga diduga karena kandungan serat larut air dan protein 
dalam kacang hijau. Serat larut air dalam kacang hijau dapat membentuk gel untuk mengikat asam empedu dari kolesterol. Serat yang dikonsumsi dapat mengikat asam empedu kemudian dikeluarkan bersama feses. ${ }^{24}$ Protein dalam kacang hijau kaya akan asam amino esensial seperti leusin, isoleusin dan valin. ${ }^{25}$ Protein dalam kacang hijau berperan sebagai antioksidan dan terlibat dalam metabolisme lipid. Leusin, isoleusin, dan valin merupakan asam amino rantai cabang yang membantu menghambat sintesis dan absorpsi kolesterol dalam usus. ${ }^{26}$

Kadar kolesterol total dapat dipengaruhi oleh beberapa faktor, salah satunya asupan makanan. Pada penelitian ini tidak terdapat perbedaan asupan makanan subjek selama intervensi. Rerata asupan makanan baik energi, protein, lemak, karbohidrat dan serat tergolong rendah dan belum mencukupi kebutuhan yang dianjurkan. Pada penelitian ini subjek pada kedua kelompok memiliki rerata kadar kolesterol total sesudah intervensi masih dalam kategori tinggi (>200 mg/dl). Hal ini dapat disebabkan oleh faktor asupan makanan yaitu konsumsi serat semua subjek selama intervensi kurang dari anjuran. Anjuran konsumsi serat sebesar 20-30 g/hari. ${ }^{11}$

Penelitian menunjukkan bahwa serat pangan, terutama serat larut air memiliki efek menurunkan kadar kolesterol total. Asupan tinggi serat larut air dapat menurunkan kolesterol total melalui beberapa mekanisme. Pertama, serat larut air mengikat asam empedu dan meningkatkan ekskresinya sehingga menurunkan kolesterol dalam tubuh. Kedua, serat larut air menghambat pembentukan asam lemak oleh produk hasil fermentasi bakteri di usus besar (produksi asam lemak rantai pendek seperti asetat, butirat, propionat) sehingga menghambat sintesis kolesterol. Serat larut air banyak terkandung dalam kacang-kacangan, buah, sayur, dan sereal. ${ }^{8,11,27}$ Sebuah penelitian pada 20 pria hiperkolesterolemia mengenai pemberian kacang-kacangan yang mengandung serat larut sebanyak $17 \mathrm{~g} / \mathrm{hari}$ mampu menurunkan kolesterol total serum sebesar $19 \%$. Penelitian lain menyimpulkan bahwa serat dapat menurunkan kolesterol saat diimbangi dengan konsumsi lemak rendah. Pada penelitian tersebut kelompok yang mengkonsumsi serat tinggi sekaligus lemak rendah mengalami penurunan kolesterol total yang lebih besar (13\%) dibandingkan kelompok yang hanya konsumsi lemak rendah $(9 \%){ }^{28}$

Pengukuran asupan makanan pada penelitian ini menggunakan metode recall 24 jam. Metode ini dilakukan dengan mencatat jenis dan jumlah bahan makanan yang dikonsumsi pada periode 24 jam yang lalu. Untuk menggambarkan kebiasaan makan individu secara representatif, recall 24 jam sebaiknya dilakukan berulang-ulang dan harinya tidak berturut-turut. Pada penelitian ini pengukuran asupan makanan dilakukan setiap hari selama intervensi. Hal ini dapat menyebabkan subjek merasa jenuh, melaporkan konsumsinya lebih sedikit (under estimate) atau lupa. Beberapa penelitian menunjukkan bahwa minimal 2 kali recall 24 jam tanpa berturut-turut, dapat menghasilkan gambaran asupan gizi lebih optimal dibandingkan hanya dilakukan 1 kali (1x24 jam), dan memberikan variasi yang lebih besar tentang asupan harian individu. ${ }^{29}$

Rerata kadar kolesterol total yang masih dalam kategori tinggi sesudah intervensi juga dapat disebabkan oleh faktor indeks massa tubuh (IMT). Sebagian besar subjek memiliki IMT $>25-30 \mathrm{~kg} / \mathrm{m}^{2}$, termasuk dalam kategori obesitas. Obesitas adalah suatu kondisi patologis dengan terdapatnya penumpukan lemak berlebihan yang diperkirakan dengan IMT $\geq 25 \mathrm{~kg} / \mathrm{m}^{2} .{ }^{30}$ Kelebihan berat badan berhubungan dengan tingginya kadar kolesterol total. ${ }^{31}$ Beberapa penelitian menunjukkan bahwa individu dengan persentase lemak tubuh yang tinggi cenderung memiliki kolesterol total tinggi dibandingkan dengan mereka yang berat badannya normal. ${ }^{32}$ Hal ini sejalan dengan penelitian di Finlandia yang menunjukkan hubungan positif antara kadar kolesterol dengan IMT pada pria dan wanita usia 30-59 tahun. ${ }^{33}$

Beberapa penelitian menunjukkan bahwa obesitas berhubungan dengan resistensi insulin. Hubungan tersebut dapat dijelaskan bahwa pada obesitas terjadi pelepasan asam lemak bebas ke dalam sirkulasi. Asam lemak bebas berasal dari lipolisis trigliserida jaringan adiposa. Makin banyak jaringan adiposa maka asam lemak bebas yang dilepaskan juga semakin meningkat. ${ }^{34}$ Peningkatan asam lemak bebas dapat meningkatkan resistensi insulin melalui acylating regulatory protein atau peningkatan metabolik lemak yang mengaktifkan protein kinase $\mathrm{C}$.

Resistensi insulin berperan dalam peningkatan sintesis kolesterol dan penurunan absorpsi kolesterol. Peningkatan sintesis kolesterol adalah hasil dari peningkatan sintesis very low density lipoprotein (VLDL). Insulin diketahui menstimulasi reseptor hati $\mathrm{X}$ (LXRs), yang meregulasi lipogenesis dan sintesis kolesterol melalui steroid regulatory binding protein serta meningkatkan ekspresi gen ABCG5 dan ABCG8 dalam usus yang menyebabkan penurunan absorpsi kolesterol. $^{35}$ 


\section{SIMPULAN}

Pemberian jus kacang hijau dengan dosis $400 \mathrm{ml} /$ hari selama 21 hari terbukti menurunkan kadar kolesterol total pria hiperkolesterolemia secara signifikan.

\section{SARAN}

Pengukuran asupan makanan menggunakan metode recall 24 jam sebaiknya dilakukan 2-3 kali dalam seminggu tanpa berturut-turut untuk menghindari subjek merasa jenuh dan melaporkan konsumsinya lebih sedikit (under estimate), sehingga data asupan makanan yang diperoleh lebih akurat.

\section{DAFTAR PUSTAKA}

1. Kementerian Kesehatan RI. Jendela data dan informasi kesehatan penyakit tidak menular. Jakarta: Kementerian Kesehatan RI, 2012.

2. Mendis S, Puska P, Norrving B, editors. Global atlas on cardiovascular disease prevention and control. Geneva: World Health Organization, 2011.

3. Khonputsa P, Veerman JL, Vos T, Aekplakorn W, Bertram M, Klafter A, et al. Joint prevalence and control of hypercholesterolemia and hypertension in Thailand: third national health examination survey. Asia-Pac J Public Health 2012;24(1):18594.

4. Denny L, et al. Prevalence and risk factors of hypercholesterolemia among thai men and women receiving health examinations. Southeast Asian J Trop Med Public Health 2006 ; vol 37:No.5.

5. Schober SE, Makuc DM, Zhang C, Kennedy SJ, Burt V. Health insurance affects diagnosis and control of hypercholesterolemia and hypertension among adults aged 20-64:United States,2005-2008. National Center for Health Statistics 2011 Jan,57:18.

6. National Institute of Health. Third report of the National Cholesterol Education Program (NCEP) expert panel on detection, evaluation, and treatment of high blood cholesterol in adults (Adult Treatment III). US: NIH Publication, 2002.

7. Hatma RD. Lipid profiles among diverse ethnic groups in Indonesia. Acta Med Indones-Indones J Intern Med 2011 Jan, 43(1):4-11.

8. European Association for Cardiovascular Prevention and Rehabilitation. ESC/EAS guidelines for the management of dyslipidaemias. European Heart Journal 2011;32: 1769-818.

9. Schober SE, Carroll MD, Lacher DA, Hirsch R. High serum total cholesterol-an indicator for monitoring cholesterol lowering efforts: U.S. Adults, 2005-2006. Centers for Disease Control and Prevention National Center for Health Statistics. [serial online] 2007 [cited 2014 May 12] Available from:

URL:
10. Badan Penelitian dan Pengembangan Kesehatan. Riset Kesehatan Dasar 2013. Jakarta: Kementerian Kesehatan RI, 2013.

11. Pujol TJ, Tucker JE, Barnes JT. Disease of the cardiovascular system. In: Nelms M, Sucher KP, Lacey K, Roth SL. Nutrition therapy and pathophysiology. 2nd ed. USA: Cengage Learning; 2011.p.283-339.

12. Yunsheng, Chiriboga, Olendzki BC, Li W, Leung $\mathrm{K}$, Hafner AR, et al. Association between carbohydrate intake and serum lipids. J Am Coll Nutr. 2006 April; 25(2):155-63.

13. Iswandari R. Studi Kandungan Isoflavon pada Kacang Hijau, Tempe Kacang Hijau, dan Bubur Kacang Hijau [Skripsi]. Semarang: Fakultas Kedokteran Universitas Diponegoro; 2008.

14. Karahalil B. Benefits and risks of phytoestrogens. In: Yildiz F, editor. Phytoestrogen in functional foods. Ankara: CRC Press;2006.p.209-39.

15. Hernawati. Perbaikan kinerja reproduksi akibat pemberian isoflavon dari tanaman kedelai. [serial online] [cited 2014 April 6] Available from URL: http://file.upi.edu/Direktori/FPMIPA/Jur._Pend._B iologi/197003311997022-Hernawati/File_12.Pdf.

16. Lin PY, Lai HM. Bioactive compounds in legumes and their germinated products. Department of Agricultural Chemistry, National Taiwan University.

17. Middleton E, Kandaswami C. Theoharides TC. The effect of plant flavonoids on mammalian cells: Implications for inflamation, heart disease, and cancer. Pharmacol rev 2000;52:673-751.

18. Tjakraprawira A, Triwahyuni P, Hondo F. Pemanfaatan kacang hijau (Phaseolus Raditus Linn) untuk menurunkan kolesterol total pada wanita hiperkolesterolemia. Prosiding Seminar Kontribusi Fisika (SKF); 2013 Dec 2-23; Bandung, Indonesia.

19. Agdeppa IA. Nutrients in Vegetable Juice Easily Absorbed by the Body [serial online] 2006 [cited]. Available from: URL: http://www.fnri.dost.gov.ph

20. Zhan S, Ho SC. Meta-analysis of the effects of soy protein containing isoflavones on the lipid profile. Am J Clin Nutr 2005;81:397-408.

21. Howes JB, Sullivan D, Lai N, Nestel P, Pomeroy S, West $\mathrm{L}$, et al. The effect of dietary supplementation with isoflavones from red clover on the lipoprotein profiles of post menopausal women with mild to moderate hypercholesterolemia. Atherosclerosis 2000;152:143-7.

22. Haring R, Baumeister SE, Volzke H, Door M, Felix SB, Kroemer HK, et al. Prospective association of low total testosterone concentration with an adverse lipid profile and increased incident dyslipidemia. European Journal of Cardiovascular Prevention and Rehabilitation.2011;18(1):86-96.

23. Alberta Medical Association. Building healthy lifestyles vascular protection dyslipidemia clinical guidence. 2006. http://www.ncbi.nlm.nih.gov/pubmed/19389314 
24. Bazzano LA. Effects of soluble dietary fiber on low-density lipoprotein cholesterol and coronary heart disease risk. Current Atherosclerosis Reports 2008; 10:473-7.

25. Mubarak AE. Nutritional and antinutritional factors of mung bean seeds as affected by some home traditional processes. Food Chemistry 2005;89:489-95.

26. Pal S., Ellis V, Dahliwal S. Effecs of whey protein isolate in body composition, lipids, insulin in overweight and obese individual. British Journal of Nutrition 2010;104:716-23.

27. Reymond JL, Sarah CC. Medical nutrition therapy for cardiovascular disease. In: Mahan LK, Sylvia ES, Janice LR. Krause's food and the nutrition care process. $13^{\text {th }}$ ed. USA: Elsevier saunders; 2012.p.742-81.

28. Institute of Medicine of the National Academies. Chapter 7 : Dietary, functional, and total fiber. In: Dietary reference intake for energy, carbohydrate, fiber, fat, fatty acids, cholesterol, protein, and amino acids. Washington DC: The national academic press; 2005:339-421.

29. Supariasa IDN, Bakri B, Fajar I. Penilaian status gizi. Jakarta: Penerbit buku kedokteran EGC, 2002.

30. Dewi M. Resistensi insulin terkait obesitas: mekanisme endokrin dan intrinsik sel. Jurnal Gizi dan Pangan. Juli 2007;2(2):49-54.

31. Fletcher B, Berra K, Ades P, Braun LT, Burke LE, Durstine L, et al. Managing Abnormal Blood Lipids: A Collaborative Approach. Circulation. 2005;112:3184-209.

32. Karyadi E. Kiat mengatasi diabetes, hiperkolesterolemia, stroke. Jakarta: PT. Intisari Mediatama; 2006.

33. Mawi M. Indeks massa tubuh sebagai determinan penyakit jantung koroner pada orang dewasa berusia diatas 35 tahun. J Kedokteran Trisakti 2003;23(3):87-92.

34. Cahjono H, Gde Budhiarta AA. Hubungan resistensi insulin dengan kadar nitric oxide pada obesitas abdominal. J Peny Dalam. Januari 2007;8(1):23-36.

35. Pihlajamaki J, Gylling H, Miettinen TA, Laakso M. Insulin resistance is associated with increased cholesterol synthesis and decreased cholesterol absorption in normoglycemic men. Journal of Lipid Research 2004;45:507-12. 